\title{
Effect of Boron Active Belite Cement on the Compressive Strength of Concrete Exposed to High Temperatures
}

\author{
Abdulkadir Cüneyt Aydın", * Ülviye Gülsüm Haşiloğlu Aras², Türkay Kotan , Ali Öz ${ }^{1}$ \\ ${ }^{1}$ Department of Civil Engineering, Atatürk University, Erzurum, Turkey \\ ${ }^{2}$ Department of Civil Engineering, Gaziantep University, Gaziantep, Turkey \\ ${ }^{3}$ Department of Civil Engineering, Erzurum Technical University, Erzurum, Turkey \\ Email address: \\ acaydin@atauni.edu.tr (A. C. Aydın), muhugh@hotmail.com (Ü. G. H. Aras), turkay.kotan@erzurum.edu.tr (T. Kotan), \\ alioz@atauni.edu.tr (A. Öz) \\ ${ }^{*}$ Corresponding author
}

\section{To cite this article:}

Abdulkadir Cüneyt Aydın, Ülviye Gülsüm Haşiloğlu Aras, Türkay Kotan, Ali Öz. Effect of Boron Active Belite Cement on the Compressive Strength of Concrete Exposed to High Temperatures. Journal of Civil, Construction and Environmental Engineering.

Vol. 3, No. 3, 2018, pp. 47-52. doi: 10.11648/j.jccee.20180303.11

Received: May 31, 2018; Accepted: June 21, 2018; Published: July 16, 2018

\begin{abstract}
The boron active belite (BAB) cement is a cement type different from Portland cement due to the presence of $\mathrm{B}_{2} \mathrm{O}_{3}$ at 3-4\%, low hydration temperature, low early strength and high final strength. In this study, concretes with three similar gradations were produced using BAB, CEM I 42.5 and CEM II 32.5 cements. Prepared cylindrical (Ø100/200 mm) concrete samples were exposed to high temperatures of 200,400 and $600^{\circ} \mathrm{C}$ at the end of $7^{\text {th }}, 28^{\text {th }}$ and $90^{\text {th }}$ days of standard water curing periods. Then, the compressive strength, ultrasonic pulse velocity and Schmidt hammer strength properties of the concretes were investigated to determine their resistance to high temperatures. As a result, the compressive strength values of concrete with $\mathrm{BAB}$ cement were found to be higher in the final period than in concrete with normal Portland cement. Therefore, it can be said that the concretes produced with $\mathrm{BAB}$ cement is more durable against elevated temperatures from concretes produced with normal Portland cement. Moreover, the observed strength differences in concretes with BAB cement, were discussed in the light of current information in the literature.
\end{abstract}

Keywords: Concrete, Boron Active Belite Cement, Compressive Strength, High Temperature, Ultrasonic Pulse Velocity

\section{Introduction}

Turkey has 803 million tons of boron reserves, which constitute $63 \%$ of the total boron reserves around the world. The most important boron ores are tincal, colemanite and ulexite in Turkey. The products obtained from them are concentrated tincal, borax pentahydrate, decahydrate borax, anhydrous borax, boric acid and sodium perborate. Turkey is the second producer following the United States with 1.72 million tons boron minerals and compounds production. In Etibank Kirka Borax Plants, 800.000 tons/year of concentrated tincal, 160.000 tons/year of borax pentahydrate, 60.000 tons/year of anhydrous borax and 17.000 tons/year of borax decahydrate are obtained [1, 2]. Annually, 120.000 tons clay wastes $(\mathrm{CW})$, known as the first clay waste (CW1) and the second clay waste (CW2), form in the concentrated tincal unit and the borax pentahydrate unit during the production. CW containing about $8-22 \% \mathrm{~B}_{2} \mathrm{O}_{3}$ is discharged to the plant area. These wastes contain boron oxide in quite high concentrations, so this is an environmental pollution problem as well as an economic loss [3].

The utilization of various industrial wastes is important for saving the environment from degradation. Thus, their use as additives in the production of cement and mortar has been the subject of investigation in recent years. The effect of wastes on the physical and mechanical properties of cements was investigated $[4,5]$.

Being the most important raw material of cement production, limestone $\left(\mathrm{CaCO}_{3}\right)$ is primarily used as a $\mathrm{CaO}$ requirement. During the calcination process $\left(\mathrm{CaCO}_{3}+\right.$ energy $\left.\rightarrow \mathrm{CaO}+\mathrm{CO}_{2}\right)$, limestone $\left(\mathrm{CaCO}_{3}\right)$ is calcined at a temperature above $900^{\circ} \mathrm{C}$ and as a result of this process a high amount of $\mathrm{CO}_{2}$ gas is emitted to the atmosphere. On the other hand, colemanite incorporates $\mathrm{CaO}$ component, thus it 
can be directly used in cement production without any precalcination operation. Using approximately $3-5 \% \mathrm{CW}$ in the process of cement production, the amount of $\mathrm{CaCO}_{3}$ to be used in cement production is reduced $[6,7]$. Consequently, using less amount of $\mathrm{CaCO}_{3}$ in cement production yields less energy consumption and therefore less $\mathrm{CO}_{2}$ emission. Moreover, addition of $\mathrm{CW}$ prevents the formation of $\mathrm{C}_{3} \mathrm{~S}$ (alite) phase, and instead of $\mathrm{C}_{3} \mathrm{~S}$ (alite), a more active and stable belite phase of $\mathrm{C}_{2} \mathrm{~S}$ (belite) is formed. That is why the cement is called as belite cement (BAB). Since $\mathrm{C}_{2} \mathrm{~S}$ phase is formed at a temperature not more than $1325^{\circ} \mathrm{C}$, the clinker sintering temperature decreases from $1450^{\circ} \mathrm{C}$ (for OPC) to $1325^{\circ} \mathrm{C}$. The decrease in the temperature provides approximately $8.6 \%$ energy saving. During the production of industrial pilot scale, $\mathrm{CO}_{2}$ emission is reduced approximately $25 \%$ [8]. Thus, considering the above discussion, BAB production appears to be more environmentally friendly when compared to OPC production. Therefore, it is important to conduct researches on the usability of $\mathrm{BAB}$ cement in different engineering applications [9-11].

The aim of this study is to investigate the compressive strength, ultrasonic pulse velocity, and Schmidt hammer strength properties of the concretes that were exposed to high temperatures of 200,400 and $600^{\circ} \mathrm{C}$ to compare their fire resistance with ordinary Portland cements and boron active belite cement.

\section{Experimental Program}

\subsection{Materials}

This study was carried out in Construction Materials Laboratory at the Department of Civil Engineering, Atatürk
University in Erzurum, Turkey. The colemanite ore waste modified active belite cement, CEM II 32.5 and CEM I 42.5 type ordinary Portland cement (OPC) were used in the study. CEM I 42.5 and CEM II 32.5 were provided from Aşkale Cement Plant in Erzurum and Boron Active Belite (BAB) from National Boron Research Institute in Ankara, Turkey. The chemical compositions, physical and mechanical properties of these cements are shown in Table 1.

Table 1. Chemical compositions, some physical and mechanical properties of cements.

\begin{tabular}{|c|c|c|c|c|}
\hline \multicolumn{2}{|c|}{ Composition (\%) } & $\begin{array}{l}\text { CEM I } \\
42.5 R\end{array}$ & $\begin{array}{l}\text { CEM II B-M } \\
\text { (P-LL) 32.5R }\end{array}$ & BAB \\
\hline \multicolumn{2}{|l|}{$\mathrm{SiO}_{2}$} & 20.79 & 19.15 & 21.56 \\
\hline \multicolumn{2}{|l|}{$\mathrm{Fe}_{2} \mathrm{O}_{3}$} & 2.23 & 2.2 & 2.76 \\
\hline \multicolumn{2}{|l|}{$\mathrm{Al}_{2} \mathrm{O}_{3}$} & 4.78 & 4.7 & 5.15 \\
\hline \multicolumn{2}{|l|}{$\mathrm{CaO}$} & 63.41 & 56.16 & 60.74 \\
\hline \multicolumn{2}{|l|}{$\mathrm{MgO}$} & 2.26 & 2.99 & 3.38 \\
\hline \multicolumn{2}{|l|}{$\mathrm{SO}_{3}$} & 2.65 & 1.94 & 2.25 \\
\hline \multicolumn{2}{|l|}{$\mathrm{Cl}^{-}$} & 0.0172 & 0.0187 & 0.0354 \\
\hline \multicolumn{2}{|l|}{ Loss on Ignition } & 2.36 & 11.38 & 2.43 \\
\hline \multicolumn{2}{|c|}{$\mathrm{Na}_{2} \mathrm{O}$} & 0.38 & 0.34 & 0.47 \\
\hline \multicolumn{2}{|c|}{ Specific Surface $\left(\mathrm{cm}^{2} / \mathrm{g}\right)$} & 4089 & 4911 & 3646 \\
\hline \multicolumn{2}{|c|}{ Specific Gravity $\left(\mathrm{gr} / \mathrm{cm}^{3}\right)$} & 3.11 & 2.96 & 3.08 \\
\hline Comp. Strength & 2 days & 30.4 & 22 & 12.7 \\
\hline$(\mathrm{MPa})$ & 28 days & 59.8 & 45 & 35.8 \\
\hline
\end{tabular}

The crushed aggregate was supplied from Aşkale Cement sand quarry in Erzurum. Obtained aggregates were classified according to $0 / 2,2 / 8,8 / 16$ grain grades. In this study, particle sizes of the proportions were $40 \%$ of $0 / 2,25 \%$ of $2 / 8$ and $35 \%$ of $8 / 16$, respectively. The gradation graph of mixture aggregate was shown in Figure 1. In total, 108 cylindrical $(\varnothing 100 / 200 \mathrm{~mm})$ concrete specimens were prepared in this study.

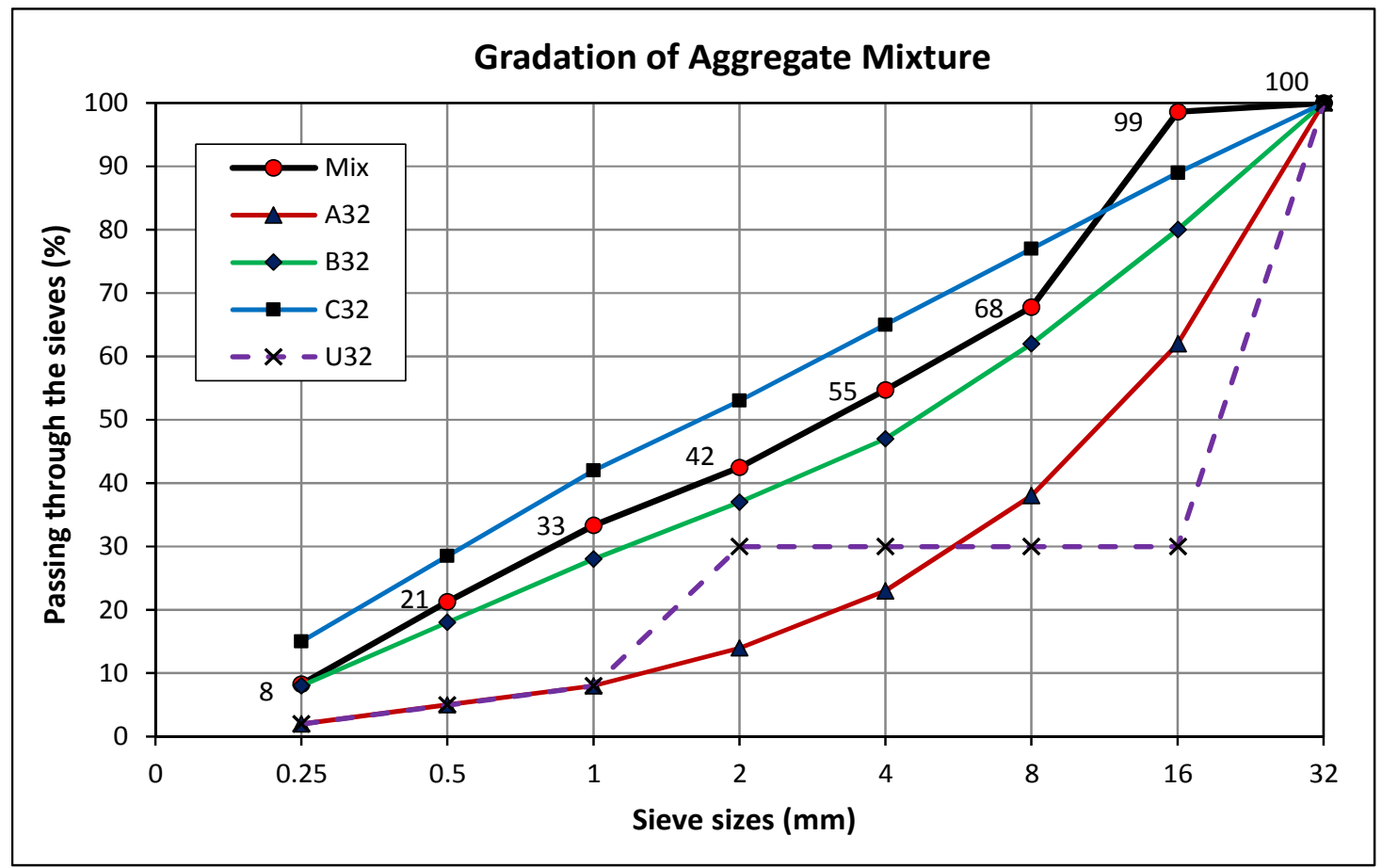

Figure 1. The gradation graph of aggregate mixture. 


\subsection{Methods}

For the production of the concrete samples, modular sand and each cement were mixed. Water gradually was added in preparation of mortar during mixing. For $1 \mathrm{~m}^{3}$ concrete, the mix proportions of the components were given in Table 2 . The mortar samples were poured in $\varnothing 100 / 200 \mathrm{~mm}$ moulds, were compacted by means of an iron rod and were vibrated by a vibrator to settle down the mortar. After the vibration operation, a steel ruler planed the open surfaces of the concretes in moulds. For this study, totally 108 specimens (27 specimens for each type of concretes) were produced. The specimens were divided into the 9 subgroups $(n=3)$ in each control, 200, 400 and $600^{\circ} \mathrm{C}$ heating temperatures were applied for three curing periods (7,28 and 90 days) and three cement types (CEM I 42.5), and CEM II32.5 and BAB).

Table 2. The proportions of concrete mixture.

\begin{tabular}{llllllll}
\hline \multirow{2}{*}{ Mixture } & CEM I & CEM II & BAB & Water & \multicolumn{3}{c}{ Aggregate (kg) } \\
\cline { 6 - 9 } & $\mathbf{4 2 . 5}(\mathbf{k g})$ & $\mathbf{3 2 . 5}(\mathbf{k g})$ & $\mathbf{( k g )}$ & $\mathbf{( k g )}$ & $\mathbf{0 / 2}$ & $\mathbf{2 / 8}$ & $\mathbf{8 / 1 6}$ \\
\hline M1 & 308 & - & - & 170 & 285 & 178 & 249 \\
M2 & - & 294 & - & 170 & 285 & 178 & 249 \\
M3 & - & - & 305 & 170 & 285 & 178 & 249 \\
\hline
\end{tabular}

In the first stage of hydration, the moulds were left to a medium having $90 \%$ moisture for $24 \mathrm{~h}$ and then, the concrete samples taken from the moulds were left to dock filled with lime-saturated water for 7, 28 and 90 days. After water curing, the concrete specimens were left for drying in ambient air.

In this study, control group were usually reserved from total specimens. The compressive strength, ultrasonic pulse velocity and Schmidt hammer strength measurements were carried out over control group on the $7^{\text {th }}, 28^{\text {th }}$ and $90^{\text {th }}$ days. Other specimens were kept in drying oven at the fire temperatures of $200^{\circ} \mathrm{C}, 400^{\circ} \mathrm{C}$ and $600^{\circ} \mathrm{C}$. Duration of fire temperature was $180 \mathrm{~min}$. In each case of fire temperature, three cylindrical specimens were tested and recorded for CEM II 32.5, CEM I 42.5 and BAB separately. After being exposed to different fire temperatures at a fixed duration of 180 min, all CEM II 32.5, CEM I 42.5 and BAB cylindrical specimens were first cooled down to room temperature and then mechanically tested to determine their residual compressive strengths. Before compressive strength was done, ultrasonic pulse velocity and Schmidt hammer measurements were carried out for these specimens.

The compressive strength, ultrasonic pulse velocity and Schmidt hammer strength test results of the concrete samples were formulated by means of Statistica software. The test results and the determinations obtained from those are explained in the following chapter.

\section{Results and Discussions}

In this study, as a necessary property in concrete, the compressive strength measurements were calculated as arithmetic average of the three specimens. For the BAB, CEM I 42.5 and CEM II 32.5 control groups in water curing, the 7day average compressive strengths are 17.74, 23.64 and 16.87 $\mathrm{Mpa}$, the 28-day average compressive strengths are 26.41, 31.83 and $32.5 \mathrm{Mpa}$, the 90 -day average compressive strengths are $39.61,33.36$ and $31.03 \mathrm{Mpa}$, respectively. There is a decrease in the workability of the concrete mixes with the noninclusion of admixture. Extra water was added to the mix in order to catch the desired slump value of mix for this reason. Hence, there was a decrease in the compressive strength of the concrete mixes due to increasing of water/cement rate.

The fire endurance temperature of the concrete is an important material property employed to evaluate its fire resistance at higher temperatures. Hence, the compressive strengths of BAB, CEM I 42.5 and CEM II 32.5 specimens suffered from fire duration of 0 and $180 \mathrm{~min}$ at different temperatures were measured.

The 7-day, 28-day and 90-day average compressive strength losses of BAB, CEM I 42.5, CEM II 32.5 specimens were listed in Table 3 . The compressive strengths of $\mathrm{BAB}$, CEM I 42.5 and CEM II 32.5 specimens in the ages of 7, 28, 90 days are shown in Figure 2. As shown in Figure 2, even if the highest compressive strength values belongs to CEM I 42.5 at the 7-day and 28-day, the highest compressive strength value belong to $\mathrm{BAB}$ at the 90 -day.

Table 3. The 7, 28, 90-day compressive strength variation of BAB, CEM I 42.5, CEM II 32.5.

\begin{tabular}{|c|c|c|c|c|c|}
\hline $\begin{array}{l}\text { Curing } \\
\text { Period }\end{array}$ & $\begin{array}{l}\text { Cement } \\
\text { Type }\end{array}$ & $\begin{array}{l}\text { Standard Cured } \\
(\mathrm{MPa})\end{array}$ & $\begin{array}{l}\text { Heated up to } 200^{\circ} \mathrm{C} \\
\text { (MPa) }\end{array}$ & $\begin{array}{l}\text { Heated up to } 400^{\circ} \mathrm{C} \\
\text { (MPa) }\end{array}$ & $\begin{array}{l}\text { Heated up to } 600^{\circ} \mathrm{C} \\
\text { (MPa) }\end{array}$ \\
\hline \multirow{3}{*}{7 days } & $\mathrm{BAB}$ & 17.74 & $17.26(-2.71 \%)$ & $12.70(-28.41 \%)$ & $5.95(-66.46 \%)$ \\
\hline & CEM I 42.5 & 23.64 & $21.60(-8.63 \%)$ & $17.89(-24.32 \%)$ & $10.55(-55.37 \%)$ \\
\hline & CEM II 32.5 & 16.87 & $16.78(-0.53 \%)$ & $11.55(-31.54 \%)$ & $6.53(-61.29 \%)$ \\
\hline \multirow{3}{*}{28 days } & $\mathrm{BAB}$ & 26.41 & $21.58(-18.29 \%)$ & $19.49(-26.20 \%)$ & $10.34(-60.85 \%)$ \\
\hline & CEM I 42.5 & 31.83 & $26.44(-16.93 \%)$ & $21.71(-31.79 \%)$ & $11.58(-63.62 \%)$ \\
\hline & CEM II 32.5 & 22.46 & $19.07(-15.09 \%)$ & $16.24(-27.69 \%)$ & $7.92(-64.74 \%)$ \\
\hline \multirow{3}{*}{90 days } & $\mathrm{BAB}$ & 39.61 & $29.07(-26.61 \%)$ & $24.37(-38.48 \%)$ & $11.35(-71.35 \%)$ \\
\hline & CEM I 42.5 & 33.36 & $24.66(-26.08 \%)$ & $14.86(-55.46 \%)$ & $8.25(-75.27 \%)$ \\
\hline & CEM II 32.5 & 31.03 & $21.36(-31.16 \%)$ & $22.94(-26.07 \%)$ & $12.79(-58.78 \%)$ \\
\hline
\end{tabular}

${ }^{*}$ Standard cured samples are cured in water up to one day before testing.

${ }^{* *}$ Heated samples are tested after air-cooling to room temperature.

${ }^{* * *}$ The percentages given in parenthesis show the decrease of compressive strength 


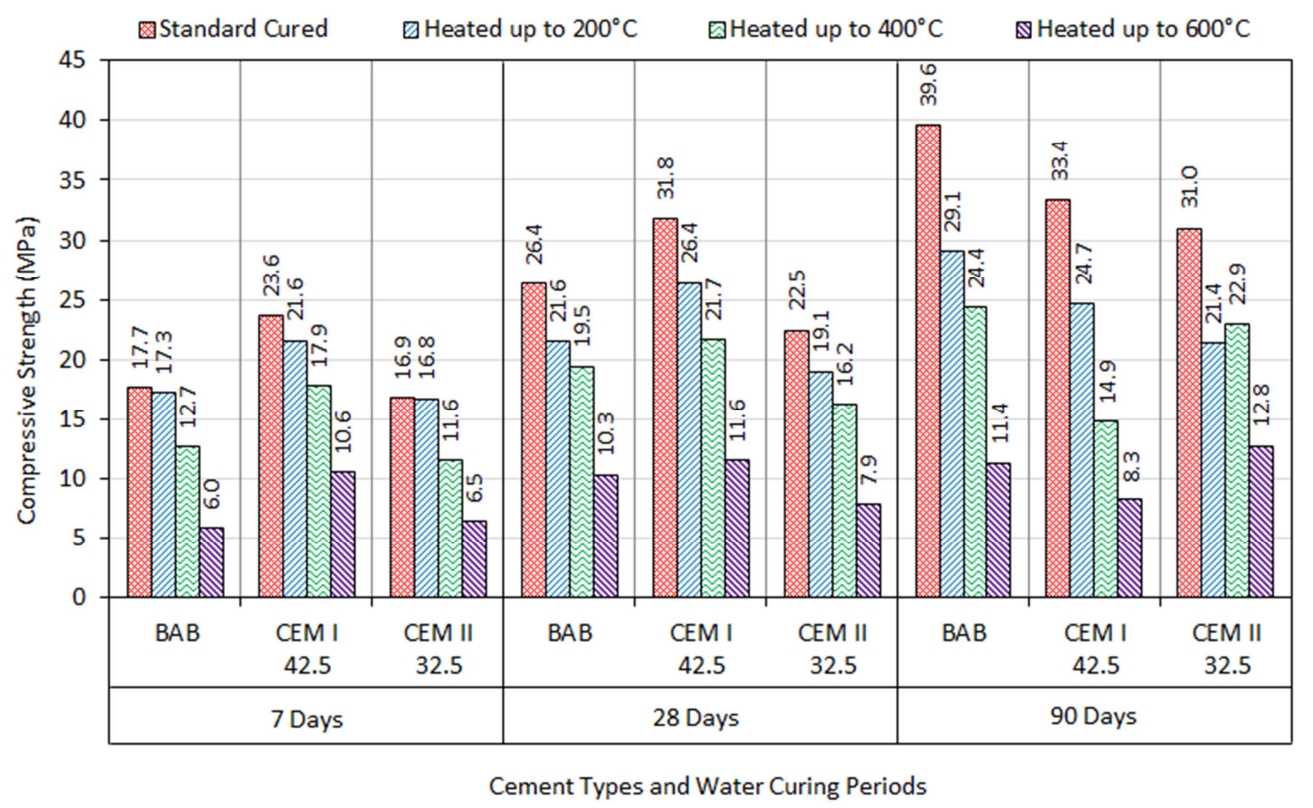

Figure 2. The 7, 28, 90-day compressive strength of BAB, CEM I 42.5, CEM II 32.5.

When the specimens cured in water for 7, 28 and 90 days were heated up to $200^{\circ} \mathrm{C}$, the strength losses were determined generally in all concrete types. The results showed that there is a linear relationship between the changes in strength loss with the extensions of water curing period. Thus, it was noticed that the decrease in the strength of the specimens cured for 7 day and heated at $200^{\circ} \mathrm{C}$ for 180 minutes did not occur. In addition, the strength loss values of the specimens heated at $200^{\circ} \mathrm{C}$ for 180 minutes for 90 days dramatically decreased. Due to the fact that the concretes cured for short term did not reach the strength high enough yet, it may be interpreted as serious strength loss does not occur. Such that, the serious strength losses are seen in concrete specimens heated up to $400^{\circ} \mathrm{C}$ and $600^{\circ} \mathrm{C}$ for all experimental groups and all curing times. In this case, it may be interpreted that the concrete texture are affected adversely in the concretes heated to elevated temperatures and thus the loss of strength occurs clearly. Decrease of the concrete strength at elevated temperatures, expansion of aggregates, expansion of cement, dehydration of water at voids of concrete and cement compound as a set of physical and chemical phenomenon may be explained. The Calcium Silica Hydrate (CSH) composed gel structure of cement paste connects soil particles to each other by means of adsorption water. Gel adsorption water and hydrate water in CSH are easily non-volatile type, however water in capillary voids can evaporate at $100^{\circ} \mathrm{C}$. Thus, density of CSH gels in concrete acting as connectivity decrease, and it cause serious loss of strength. Emerging effects of aggregates during fire become visible in due course of heating. Having more different thermic expansion coefficient from cement paste phase, aggregates cause shear stress in this phase thereby cracking concrete cause to lose continuity [12].

The concrete specimens were cured in water for 7, 28 and 90 days, then Schmidt hammer, known as non-destructive testing method, were applied to concretes as pre and post heat treatment. In all experimental groups, there was not a significant change in the Schmidt hammer values of the concretes heated up to $200^{\circ} \mathrm{C}$. The Schmidt hammer values of the concretes cured in water for 7 days and heated up to $400^{\circ} \mathrm{C}$ showed insensible increase. However, an insensible decrease was observed in the Schmidt hammer values of the concretes heated up to $400^{\circ} \mathrm{C}$ and cured in water for 28 and 90 days. The most obvious changes in this data occurred in the concrete heated to $600^{\circ} \mathrm{C}$. In the Schmidt hammer values of the concretes heated to $600^{\circ} \mathrm{C}$ compared to pre-heating, the obvious decreases occurred for all curing periods (Table 4).

Table 4. The Schmidt hammer values.

\begin{tabular}{|c|c|c|c|c|c|}
\hline $\begin{array}{l}\text { Curing } \\
\text { Period }\end{array}$ & Cement Type & $\begin{array}{l}\text { Standard Cured } \\
(\mathrm{MPa})\end{array}$ & $\begin{array}{l}\text { Heated up to } 200^{\circ} \mathrm{C} \\
\text { (MPa) }\end{array}$ & $\begin{array}{l}\text { Heated up to } 400^{\circ} \mathrm{C} \\
\text { (MPa) }\end{array}$ & $\begin{array}{l}\text { Heated up to } 600^{\circ} \mathrm{C} \\
\text { (MPa) }\end{array}$ \\
\hline \multirow{3}{*}{7 days } & $\mathrm{BAB}$ & 17.33 & 18.67 & 18.00 & 13.00 \\
\hline & CEM I 42.5 & 21.50 & 21.33 & 23.33 & 9.00 \\
\hline & CEM II 32.5 & 14.89 & 15.00 & 17.00 & 12.00 \\
\hline \multirow{3}{*}{28 days } & $\mathrm{BAB}$ & 19.17 & 21.00 & 17.00 & 12.00 \\
\hline & CEM I 42.5 & 21.00 & 24.00 & 19.00 & 17.33 \\
\hline & CEM II 32.5 & 16.83 & 18.67 & 17.33 & 14.00 \\
\hline \multirow{3}{*}{90 days } & $\mathrm{BAB}$ & 22.00 & 20.67 & 18.67 & 13.33 \\
\hline & CEM I 42.5 & 18.08 & 18.33 & 16.67 & 16.33 \\
\hline & CEM II 32.5 & 18.58 & 18.33 & 19.00 & 14.67 \\
\hline
\end{tabular}

* Standard cured samples are cured in water up to one day before testing.

** Heated samples are tested after air-cooling to room temperature. 
Besides, the Ultrasonic Pulse Velocity (UPV), known as another non-destructive testing method, was also applied to concrete specimens cured in water for 7, 28 and 90 days at pre and post heat treatment. The quality of concrete in terms of uniformity, incidence or absence of internal flaws, cracks and segregation etc. indicates the level of workmanship employed, thus can be assessed using the guidelines given below (Table 5), which have been evolved for characterizing the quality of concrete in structures in terms of the ultrasonic pulse velocity.

Table 5. The ultrasonic pulse velocity values $(\mathrm{m} / \mathrm{s})$.

\begin{tabular}{|c|c|c|c|c|c|}
\hline $\begin{array}{l}\text { Curing } \\
\text { Period }\end{array}$ & Cement Type & $\begin{array}{l}\text { Standard Cured } \\
(\mathrm{MPa})\end{array}$ & $\begin{array}{l}\text { Heated up to } 200^{\circ} \mathrm{C} \\
(\mathrm{MPa})\end{array}$ & $\begin{array}{l}\text { Heated up to } 400^{\circ} \mathrm{C} \\
\text { (MPa) }\end{array}$ & $\begin{array}{l}\text { Heated up to } 600^{\circ} \mathrm{C} \\
\text { (MPa) }\end{array}$ \\
\hline \multirow{3}{*}{7 days } & $\mathrm{BAB}$ & 3935.18 & 3613.00 & 2530.00 & $-^{* * *}$ \\
\hline & CEM I 42.5 & 4161.89 & 3697.37 & 2701.47 & 1512.33 \\
\hline & CEM II 32.5 & 3864.24 & 3405.00 & 1904.00 & $-^{* * *}$ \\
\hline \multirow{3}{*}{28 days } & $\mathrm{BAB}$ & 4471.75 & 4066.00 & 3041.67 & 1265.00 \\
\hline & CEM I 42.5 & 4218.88 & 3785.00 & 3190.00 & 1783.67 \\
\hline & CEM II 32.5 & 4228.33 & 3771.00 & 2663.33 & 1483.33 \\
\hline \multirow[t]{2}{*}{90 days } & CEM I 42.5 & 4232.50 & 3739.33 & 2616.67 & 1352.00 \\
\hline & CEM II 32.5 & 4053.33 & 3796.67 & 3283.67 & 1773.67 \\
\hline
\end{tabular}

* Standard cured samples are cured in water up to one day before testing.

** Heated samples are tested after air-cooling to room temperature.

*** Could not be observed

Table 6. The concrete quality grading according to Ultrasonic Pulse Velocity.

\begin{tabular}{ll}
\hline Ultrasonic Velocity $(\mathbf{m} / \mathbf{s})$ & Concrete Quality Grading \\
\hline Above 4500 & Excellent \\
$3500-4500$ & Good \\
$3000-3500$ & Medium \\
Below 3000 & Doubtful \\
\hline
\end{tabular}

As can be seen from Table 6, the first measurement of the ultrasonic pulse velocity prominently increased for concrete types with BAB and CEM II 32.5 cement from the $7^{\text {th }}$ day to $28^{\text {th }}$ day for all curing periods. However, these values dropped from the $28^{\text {th }}$ day to $90^{\text {th }}$ day. More specifically, this drop occurred in the concrete samples with CEM II 32.5 cement. This case was remarkable. It was found that the first measurement of ultrasonic pulse velocity insignificantly increased in the concrete with CEM I 42.5 from the $7^{\text {th }}$ day to $90^{\text {th }}$ day.

The maximum pre-UPV value was $4471.75 \mathrm{~m} / \mathrm{s}$. This value belongs to a specimen with $\mathrm{BAB}$ cement. As compared to $\mathrm{BAB}$ specimens and the others, $\mathrm{BAB}$ concretes have larger UPV values for 28 days and 90 days ultrasonic results before fire. By conducting a series of fire resistance tests, it is found that the concrete's residual compressive strength decreases with the increasing fire duration. As compared to CEM I 42.5 and CEM II 32.5, the BAB cement has a higher fire endurance temperature especially for the both 28 and 90 days except for $600^{\circ} \mathrm{C}$. However, during fire endurance temperature tests, it was found that the explosive spalling occurred in CEM II 32.5 and BAB specimens cured for 7 days when the temperature of furnace was increased up to near $600^{\circ} \mathrm{C}$.

\section{Conclusion}

In this study, for the concrete samples produced with $\mathrm{BAB}$, CEM I 42.5 and CEM II 32.5 cements, the obtained results from the compressive strength, Schmidt hammer and ultrasonic pulse velocity tests can be summarized as follows:

In general, the compressive strengths of each three concrete types gradually showed increase for the 7,28 and 90-days water curing periods as expected. For each water curing period and concrete type, the highest compressive strengths were obtained in standard cured concrete series, however the compressive strengths of the specimens heated up to $200^{\circ} \mathrm{C}, 400^{\circ} \mathrm{C}$ and $600^{\circ} \mathrm{C}$ gradually decreased.

In this study, the highest compressive strength was determined as $39.61 \mathrm{MPa}$ only in the standard cured concrete type with $\mathrm{BAB}$ cement for 90-days curing period, the lowest compressive strength was also determined as $5.95 \mathrm{MPa}$ in concrete type with $\mathrm{BAB}$ cement heated up to $600^{\circ} \mathrm{C}$ for 90 days curing period. The compressive strength values of the concretes with $\mathrm{BAB}$ cement in the late periods were higher from others. Thus, it can be said that the concretes produced with $\mathrm{BAB}$ cement is more durable against elevated temperatures from others.

The elevated temperatures applied to concrete samples caused strength losses up to $75 \%$ according to the strengths of standard cured specimens and this highest strength loss was determined in concrete type with CEM I 42.5 cement heated up to $600^{\circ} \mathrm{C}$ for 90 -days curing period. The strength losses of the concrete specimens heated up to $200^{\circ} \mathrm{C}$ consistently showed increase, this case can be explained by that the concrete samples did not reach sufficiently high strength in short curing periods. However, for the concrete types heated up to $400^{\circ} \mathrm{C}$ and $600^{\circ} \mathrm{C}$, there is no similar relationship between the curing periods and strength loss. This case can also be interpreted as; whether the concretes gain sufficient strength or not, higher temperatures caused negative effects in the structure of concrete and thus, the strength losses became more apparent. The Schmidt hammer and ultrasonic pulse velocity test results of the samples generally showed a similar tendency to compressive strength results. 


\section{References}

[1] Güyagüler, T., 2001, Boron Potantial of TURKEY, 4th Industrial Stock Symposium, Ankara, TURKEY, pp.18-27.

[2] Smith, R., McBroom R., 1992. Boron Compounds, Kirk Othmer Encyclopedia of Chemical Technology, John Wiley, Canada.

[3] Özdemir, M., Öztürk, N. U., Utilization of clay wastes containing boron as cement additives. Cement and Concrete Research, 33 (2003) 1659-1661. DOI: 10.1016/S00088846(03)00138-8.

[4] Boncukcuoğlu, R., Yilmaz, M. T., Kocakerim M. M., Tosunoğlu, V., Utilization of trommel sieve waste as an additive in Portland cement production. Cement Concrete Research, 32 (2002) 35-39. DOI: 10.1016/S00088846(01)00625-1.

[5] Shiao, S. J. and Tsai, C. M., The study on improving Masonry cement for the solidification of borate wastes. Radioactive waste management and the nuclear fuel cycle, 1989, 11(4) 319-331. WOS:A1989AV73500002.

[6] Targan, Ş., Olgun, A., Erdogan, Y., Sevinc, V., Influence of natural pozzolan, colemanite ore waste, bottom ash, and fly ash on the properties of Portland cement. Cement and
Concrete Research, 33 (2003) 1175-1182. DOI: 10.1016/S0008-8846(03)00025-5

[7] Elbeyli, İ. Y., Derun, E. M., Gülen, J., Pişkin, S., Thermal analysis of borogypsum and its effects on the physical properties of Portland cement. Cement and Concrete Research, 33 (2003) 1729-1735. DOI: 10.1016/S00088846(03)00110-8

[8] Sağlık, A., Sümer, O., Tunç, E., Kocabeyler, M. F., Çelik, R. S., Boron modified active belite (BAB) cement and its applicability for DSI projects. DSİ Teknik Bülteni, 105 (2009) 1-22 (in Turkish).

[9] Yilmaz, Y., Ozaydin, V., Compaction and shear strength characteristics of colemanite ore waste modified active belite cement stabilized high plasticity soils. Engineering Geology, 155 (2013) 45-53.

[10] Sahin, M. and Yıldırım, M. K., Boron Cement, Journal of Cemen Türk, (2016) http://www.cementurk.com.tr/Index/ArticleDetails /76

[11] Koumpouri, D., Angelopoulos, G. N., Effect of boron waste and boric acid addition on the production of low energy belite cement, Cement and Concrete Composites, (2016) 68, 1-8.

[12] Akman, M. S., Yap1 Malzemeleri. Istanbul Technical University, publication no: 1336162 pp, 1990. Istanbul, Turkey (in Turkish). 